\title{
The Impact of Services Quality, Location and Word of Mouth to Repurchase Intention through Brand Image at Salon Muslimah Beauty Care Padang
}

\author{
Putri Maurisni $^{1}$ Susi Evanita ${ }^{2}$ \\ ${ }^{1}$ Universitas Negeri Padang, Padang, Indonesia, $\triangle$ maurisniputri10@gmail.com \\ 2 Universitas Negeri Padang, Padang, Indonesia, $\bowtie$ susievanita@gmail.com
}

\begin{abstract}
This study aims to analyze the impact of services quality, location and word of mouth to repurchase intention through brand image at Salon Muslimah Beauty Care Padang.The population of this study is all consumers who visit Salon Muslimah Beauty Care Padang with a number of samples nearly 150 respondents. The analysis technique used is path analysis. The study result shows that services quality and word of mouth have a significant impact on repurchase intention through brand image at Salon Muslimah Beauty Care Padang, but location variable has no significant impact on interest to re-buy through brand image. Furthermore, the services quality and word of mouth have a significant influence on brand image, then location has no significant impact on brand image at Salon Muslimah Beauty Care Padang.

Keywords: services quality, location, word of mouth, brand image and repurchase intention
\end{abstract}

\section{Introduction}

It is undeniable that the development of modern times is causing significant changes in people's lifestyles, especially in women. As we see today, it needs help which is one of the needs of women, with a variety of ways every woman does beauty care. Likewise, with the development of businesses currently have many fields, these fields including the salon services business. Because this phenomenon causes many people to be interested in starting new businesses, especially in this case is a beauty salon.

The beauty salon service industry that is currently quite promising, this is related to women's awareness of the importance of body care by increasing the purchasing power of the Padang people. In addition, activities and jobs that take a lot of time also affect the emergence of new habits, namely caring for the body as well as taking care of themselves in leisure time.

In the news reported by Detik.com (2015), according to data compiled by L'Oreal Indonesia. Women in Indonesia at least visit the salon twice in 6 months to do various treatments. As many as 161,000 hobby people indulged in salons one year ago. With estimates there are as many as 115,000 salons that have a market value of up to Rp 1,213 trillion in 2014. Then L'Oreal Indonesia (2016), said that in total there are estimated to be around 117,000 salons in Indonesia with a market value of Rp. 1.3 trillion in 2016.

The following data from visitors using the Muslimah and Ririn Salon \& Spa beauty salon services can be seen in the following table:

Table 1 Comparison Data for Visitors Using Salon Services for Muslim Beauty Care and Padang Ririn Salon \& Spa in January - June 2018

\begin{tabular}{|l|c|c|c|c|}
\hline Month & $\begin{array}{c}\text { Number of Visitors at } \\
\text { Muslimah Beauty } \\
\text { Care (People) }\end{array}$ & $\mathbf{( \% )}$ & $\begin{array}{c}\text { Number of } \\
\text { Costumer at } \\
\text { Ririn Beauty care } \\
\text { (People) }\end{array}$ & (\%) \\
\hline July & 840 & - & 768 & - \\
\hline Agust & 845 & 0,59 & 797 & 3,77 \\
\hline September & 892 & 5,56 & 807 & 1,25 \\
\hline October & 860 & 3,58 & 815 & 0,99 \\
\hline
\end{tabular}


Table Cont...

\begin{tabular}{|l|l|l|l|l|}
\hline November & 823 & 4,30 & 825 & 1,22 \\
\hline Desember & 792 & 3,76 & 833 & 0,97 \\
\hline
\end{tabular}

sources: Muslimah Beauty Care Salon Padang \& Ririn salon and spa

Can be seen in the table above about general phenomena that are less stable. decrease in the number of visitors using the Padang Muslimah Care beauty salon. In other words, the interest in special purchases for Muslim Beauty Care Agents in Padang is also low. Can be seen the problem faced by the Salon Muslimah Beauty Salon in Padang, which is how to increase interest in buying cosmetics at the Muslimah Beauty Care salon in Padang. The decline in consumer purchases at the Padangah Muslim Care salon must be evaluated by the company in order to successfully compete wit $\mathrm{h}$ other salons, so that later it will have an impact on increasing consumer interest in repurchase.

Triastuti (2012) states that buying interest is part of buying behavior which then leads to consumer loyalty. In addition, committed customers generally accept the expansion of new products offered by the company. Yulianti et al. (2014) stated that retail success can be characterized by repeat buying behavior from customers and the ability of retailers to survive in competition with other competitors, causing customers to buy again and this is called the intention to buy back from customers to make future purchases about perceived experience.

(Tariq, Nawaz., Nawaz., \& Butt, 2013) states that is very crucial to determine the right goods on what consumers need because it will influence positively customers' intention to make purchase again. Ain and Ratnasari (2015) state that repurchase intention is a post-purchase action caused by consumers satisfaction on products that they have been purchased or consumed earlier.(Wibowo, Eddy., Ruswanti., \& Januarko, 2013) states that repurchase intentions can be called also as purchase intensity where consumers behavior who just buy product repeteadly without including feeling aspect in it. (Bhuwana \& Rangga, Made Bagus dan Ida, 2013) state that re-use intention is an act of post-purchase which is caused by perceived customer satisfaction on products that have been purchased or consumed earlier. The high purchase interest reflects the high level of consumers satisfaction in deciding to consume product after trying the product and then arising sense of like or dislike the product (Sundalangi et al., 2014).

This study uses repurchase intention indicator as transactional interest, referential interest, preferential interest and exploratory interest. There are several factors that influence the value of purchase interest. According to study conducted by (Joseph, Onyemachi, Lilian, \& Okpara, 2012),(Awi \& Chaipoopirutana, 2014), and (Pupuani \& Sulistyawati, 2013) there are seven decisive factores affecting purchasing interest such as physical environment (location), customer satisfaction, service quality, brand preferences, product quality, perceived value, and the price. But there are only two factors suggested by previous study which is considered as dominant affect to corporate value as physical environmental factors (location) and services quality.

Services quality significantly contributes to the creation of differentiation, positioning, and competitive strategy for every marketing organization, both manufacturers and service providers (Tjiptono \& Gregorius, 2011). (Adixio, Firmawan, \& Saleh, 2013) reveal that services quality can be interpreted as a measure of how well a given level of service able to match the customer's expectations. Consumers form expectations of services from many sources, such as past experience, word of mouth, and advertising. Poor or good services quality depends on the ability of service providers consistently meet customer expectations. (Agyapong, 2011) states that the quality of service in consumer's perception of how well services meet or exceed their expectations of service quality are generally recorded as an essential prerequisite and determining competitiveness to build and maintain satisfactory relationships with customers. In a study conducted (Nadya, 2015)and (Afriani \& \& Herman, 2015) services quality has positive effects which may affect consumer re-purchasing interest. It can be concluded that to give effect to re-purchasing interest customers, directly or with mediation then services quality is one of the factors driving repurchasing interest. 
According to (Tjiptono, 2006), place is a decision concerning the distribution of the ease of access to services for potential customers. Location is associated with where the company location is. Location is also said to be a decision made by a company related to where the operation is and his staff will be placed (Lupiyoadi, 2013). Furthermore, a business location is the placement of goods or services that affect consumer decisions, taking into account the area of room along with the layout, access, parking lot (Swastha \& Irawan, 2003). Location is also a business place that greatly affect a customers' desire to come and purchase (Ujang, 2004). In a study conducted by (Yudi dkk, 2016) and (Rahmi, 2016) find that location has postive effect on re-purchase, in addition (Dewi Dkk, 2015) reveals that location influences re-purchase by customers.

Word of mouth (WOM) is a form of speech communication and testimonials that people are talking about a product or service (Basalamah, 2010). Consumers will recount his experience using the products or services of a particular company, or even to the stage of recommending products or services to others (Permadi, 2014). According to (Iput, 2007), when a consumers spend money to consume a product or service, he directly also consumes an experience, which then gives the effect of perception, and ends at level of emotional satisfaction. Research conducted (Ary dkk, 2016) and (Leonnard dkk, 2017) find re-purchase interest on costumers which are influenced by word of mouth. (Ayu, 2008) states that brand image would be mediation between word of mouth and re-purchase interest on customers.

Image, according to (Kotler \& Keller, 2009) is a set of beliefs, ideas, and impressions held by someone on an object. While the brand image are perceptions and beliefs held by consumers, as reflected in the association are embedded in the memory of consumers (Kotler \& Keller, 2009). According to (Kusuma, 2016) image of the store is a totality impression in memory of consumers about the quality perception of a product and services. A study by (Komang \& I wayan, 2017) finds that brand image has an influence on purchasing interest. Brand image is one of factors determining the success of sales strategy of a company.Consumers who have a positive image of a brand would be more likely to make a purchase and have interested in re-purchase. Brand image is associations that are activated in the memory when thinking about particular brand (Shimp, 2014). More (Maya et al, 2015) finds that brand image influences repurchase intention. repurchase intention.

So from this problem the researcher wants to know the description of consumer perceptions about the Padang Muslim Beauty Salon and test whether the variables studied will solve the existing problems. Based on this background, researchers are interested in conducting research that discusses the variables that influence the interest in repurchasing in the Padang Muslim Beauty Salon by using brand image as an intervening variable.

Based on the background above, researcher is interested in conducting research entitle The Impact of Services of Quality, Location, and Word of Mouth to Purchasing Intention through Brand Image on Muslimah Beauty Care Salon in Padang.

\section{Methods}

This study is a research to see the impact of services quality, location and word of mouth to repurchcasing intention through brand image at Muslim salon beauty care Padang. Population in this study is all consumers who visit Muslim salon beauty care Padang with sample size of 150 respondents, selected based on purposive sampling. Criteria for selecting sample in this study is for consumers who have already came more than once, over 17 years old and live in Padang. Data analysis technique used is path analysis using PLS.

\section{Results and Discussion}

Path analysis is used to determine the effect of services quality variable, location and word of mouth to repurchasing inention through brand image at Muslim Salon Beauty Care Padang. From data processing with 3.0 PLS obtained the following results: 


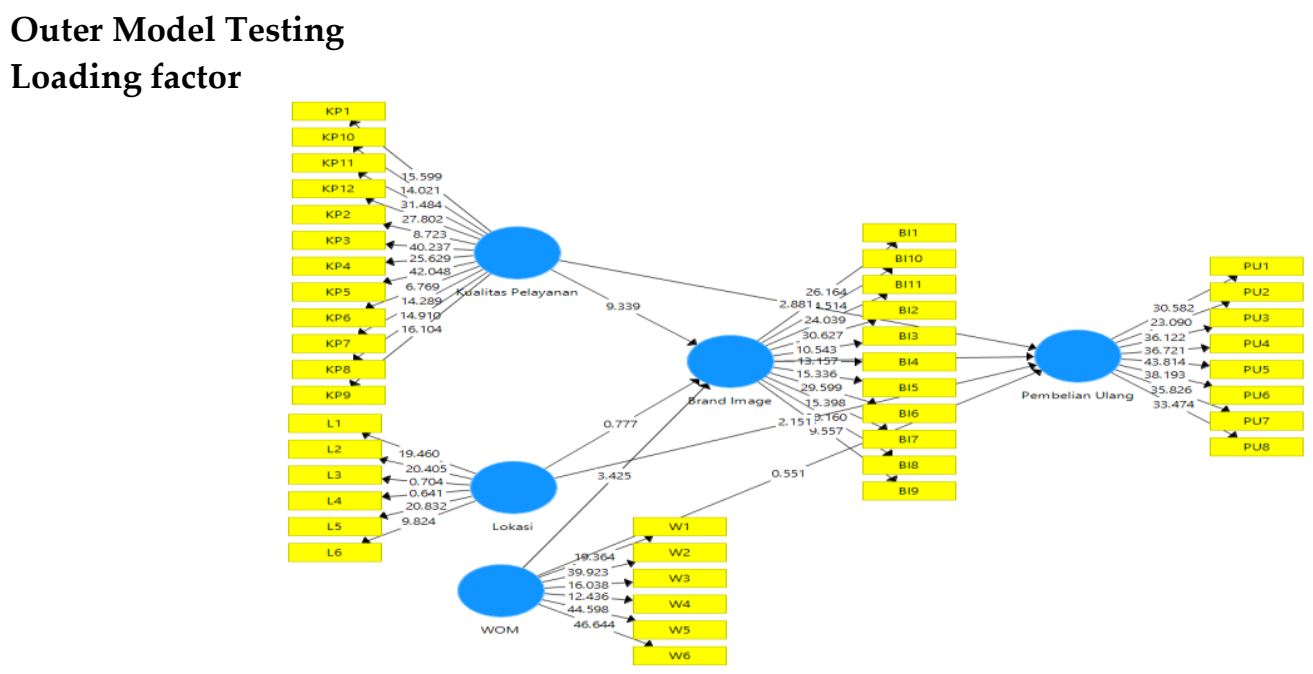

Figure 1 Structural Model Results

Source: 2019 Primary Data (Processed)

Figure 1 above shows results of the structural model in this study consisting of three independent variables, one dependent variable and one intervening variables, as well as the outer loading values on each of these variables. In services quality variable (X1) consists of five (5) indicators and 12 statements, location (X2) consists of three (3) indicator and 6 statement, word of mouth (X3) consists of three (3) indicators and 6 statement, brand image (Z) consists of five (5) indicators and 11 statements, and the purchase intention $(\mathrm{Y})$ consists of 4 (four) indicators and 8 statement.

Average Variance Extracted (AVE)

This test aims to measure variance degree of a construct components collected from indicator. It is recommended that AVE value which should be more than 0.5. Value AVE any latent variables are as follows:

Table 2 Average Variance Extracted (AVE)

\begin{tabular}{lc}
\hline Indicator & Average Variance Extracted (AVE) \\
\hline repurchase intention & 0,794 \\
\hline brand Image & .637 \\
\hline Service quality & 0,629 \\
\hline Locations & 0.502 \\
\hline WOM & 0.742
\end{tabular}

Source: 2019 Primary Data (Processed)

In the table above it can be concluded that variables in this study have met the test criteria of convergent validity.

Composite Reliability

Table 3 Cronbach's Alpha and Composite Reliability

\begin{tabular}{ccc}
\hline Variables & Cronbach's Alpha & composite Reliability \\
\hline Brand Image & 0.941 & .950 \\
\hline Service quality & 0.944 & 0.952 \\
\hline Locations & 0.735 & 0,800 \\
\hline repurchase intention & 0.963 & 0.968 \\
\hline WOM & 0,929 & 0.945
\end{tabular}

Source: Primary Data 2019 (processed)

Composite reliability is a stage that is used to test reliability of variable indicators. A reliable indicator may qualify if they have a composite reliability values $>0.6$. Reliability test with composite 
realiability method can also be amplified using Cronbach's Alpha value. A variable is said to be reliable if it has Cronbach's Alpha value $>0.7$. The following is Cronbach's alpha value and composite reliability value from each variable

Table 3 above shows each study variable fulfill criteria so that it can be concluded that all variables are reliable.

\section{Inner Model Testing \\ R-Square $\left(\mathbf{R}^{2}\right)$}

Variant Analysis $\left(\mathrm{R}^{2}\right)$ or Determination Test is to determine the influence of the independent variable to dependent variable, the coefficient value of determination can be shown in the following table:

Table 4 R-Square

\begin{tabular}{lcc}
\hline \multicolumn{1}{c}{ Variables } & R Square & R Square Adjusted \\
\hline repurchase intention & 0.504 & .490 \\
\hline brand image & .443 & 0.432 \\
\hline
\end{tabular}

In above table it can be seen that $\mathrm{R}^{2}$ repurchase intention accounting 0,504 or $50.4 \%$ were influenced by brand image, services quality, location and word of mouth, and the rest was influenced by other variables accounting $49.6 \%$ were obtained from $(100 \%-50.4 \%=49.6 \%)$. While $\mathrm{R}^{2}$ brand image variable accounting $44.3 \%$ which was influenced by services quality, location and word of mouth, and the rest influenced by others variables accounting $55.7 \%$ obrained from $(100 \%-44.3 \%=$ $55.7 \%$ ), another variable is not mentioned in this study.

\section{Hypothesis Testing}

Hypothesis 1. Services quality (X1) effected on repurchase intention (Y) with coefficient 0.280 and significant parameter 0,004 (PValues, 0.004). It can also be proved by looking at $t$ statistics of 2,881 whose greater value than $\mathrm{t}$ table ( $\mathrm{t}$ counting $2.881>t$ table 1.96). Thus, Ho was rejected and Ha was accepted, which means that services quality variable affected repurchase intention at Muslimah Beauty Salon Care Padang.

Hypothesis 2. Location (X2) effected on repurchase intentions (Y) with parameter coefficient 0.170 and significant on 0,000 (P Values, 0.032). This can be evidenced by looking at $\mathrm{t}$ statistics 2,151 whose greater value than $\mathrm{t}$ table ( $\mathrm{t} 2.151>\mathrm{T}$ table 1.96). Thus, Ho was accepted and Ha was rejected, which means that location did not affected repurchase intention at Beauty Salon Care Muslimah Padang.

Hypothesis 3. Word of mouth (X3) effected on repurchase intention (Y) with parameter coefficient 0.037 and significant to 0.002 (P Values, 0,002). This can be evidenced by looking at the $t$ statistic accounting 0.551 whose greater value than $\mathrm{t}$ table $(\mathrm{t}, 1.991>\mathrm{t}$ table 1.96). Thus Ho was rejected and $\mathrm{Ha}$ was accepted, which means that word of mouth variable influenced repurchase intention at Beauty Salon Care Muslimah Padang.

Hypothesis 4. Services quality (X1) effected on brand image (Z) with parameter coefficient 0.623 and significant at 0.000 (P Values, 0,000). This can be evidenced by looking at the $t$ statistic for 9.339 whose greater value than $\mathrm{t}$ table $(\mathrm{t}, 9.339>\mathrm{T}$ table 1.96). Thus Ho was rejected and Ha was accepted, which means that services wuality variables affected brand image at Beauty Salon Care Muslimah Padang.

Hypothesis 5. Location (X2) did not affect brand image (Z) with parameter coefficient -0.052 and significant at 0.437 (P Values 0.437). This can be evidenced by looking at the $t$ statistic for.777 whose smaller value than $\mathrm{t}$ table $(\mathrm{t}, .777<\mathrm{T}$ table 1.96). Thus, Ho was rejected and Ha was accepted, which means that location variables affected brand image at Beauty Salon Care Muslimah Padang.

Hypothesis 6. Word of mouth (X3) influenced brand image (Z) with parameter coefficient 0,210 and significant at 0.001 (P Values 0.001). This can be evidenced by looking at the $t$ statistic for 3,425 whose greater value than $t$ table $(t, 3,425>T$ table 1.96). Thus, Ho was rejected and Ha was accepted, which means that word of mouth affected brand image at Beauty Salon Care Muslimah Padang.

Hypothesis 7. Brand image (Z) effected on repurchase intention $(Y)$ with parameters coefficient .424 and significant at 0.000 ( $\mathrm{P}$ Values, 0,000 ). This can be evidenced by looking at the $t$ statistic for 4,500 whose greater value than $\mathrm{t}$ table $(\mathrm{t}, 4,500>\mathrm{T}$ table 1.96). Thus, Ho was rejected and Ha was 
accepted, which means that brand image variables affected repurchase intention at Beauty Salon Care Muslimah Padang.

Hypothesis 8 . Services quality (X1) effected on repurchase intentions ( $Y$ ) through brand image variable (Z) with parameter coefficient 0,264 and significant at 0.000 (PValues, 0,000 ). It can also be proved by looking at statistics $\mathrm{t} 3.716$ whose greater value greater $\mathrm{t}$ table $(\mathrm{t} 3.716>\mathrm{T}$ table 1.96$)$. Thus, Ho was rejected and Ha was accepted, which means that services quality variable q affected repurchase intention through brand image variable at Beauty Salon Care Muslimah Padang.

Hypothesis 9. Location (X2) effected on repurchase intentions $(\mathrm{Y})$ through a variable Brand image $(\mathrm{Z})$ with parameter coefficient -0.022 and significant 0.446 (P Values, 0.446 ). This can be evidenced by looking at $\mathrm{t}$ statistic for 0.761 whose smaller value than $\mathrm{t}$ table $(\mathrm{t} 0.761>\mathrm{T}$ table 1.96). Thus, Ho was accepted and Ha was rejected, which means that variable did not affect location of repurchase intention through brand image variable at Beauty Salon Care Muslimah Padang.

Hypothesis 10. Word of mouth (X3) effected repurchase intention $(Y)$ through brand image variable $(\mathrm{Z})$ with coefficient of 0.089 and significant parameter 0.006 (P Values, 0.006). This can be evidenced by looking at statistics 2,753 $t$ whose greater value than $t$ table $(t, 2,753>t$ table 1.96). Thus, Ho was rejected and Ha was accepted, which means that word of mouth variable influenced purchase intention variable at Beauty Salon Care Muslimah Padang.

\section{Discussion}

Based on analysis, it can be seen P-value accounting 0.004 indicating that services quality has a positive effect and significant in repurchase intention on customer of Muslimah Beauty Salon Care Padang. This means that the better services quality of impacting on repurchase intention. Companies need to improve services quality in the middle of big competition today by listening to customer's requirements and improve employee's performance and thus creating customer's satisfaction. As a result, it will create repurchase intention because if as customers are satisfied with the services provided at Muslimah Salon Beauty Care Padang to customers, they will re-purchase on that store.

The findings of this study are to prove that services quality is a factor that can influence repurchase intention because the better services, the more customers come to buy again. Therefore, the relationship of services quality with repurchase intention in a study result by the research results by (Nadya, 2015) states that services quality affects the consumer in repurchase intention, good quality services is proportional to the consumer's interest to re-purchase.

\section{Effect of Location to Repurchase Intention}

Based on analysis, it can be seen that P-value of 0.032 which indicates that services quality has positive effect and significant in repurchase intention for customer's at Muslimah Care Beauty Salon Padang. This means that the better location, the greater impact to repurchase intention. Companies need to pay attention to location and accessible location where this takes consideration for customers, the customer will naturally continue to make purchase at Muslimah Care Beauty Salon Padang and to increase profits and kepp survive on the thight competition.

The result of the study is consistent with previous studies conducted by (Yudi dkk, 2016) who states that location gives significant and positive effect to repurchase intention at Fery Showroom Padang. Furthermore, according to (Rahmi, 2016) finds the same result that location is significant effect to repurchase intention in Bekasi Junction Lotte Mart.

\section{Word of Mouth Effects on Repurchase Intention}

Based on analysis result, it can be seen that P-value of 0.002 shows that word of mouth has positive and significant effect on purchasing intention at customer's Muslimah Beauty Salon Care Padang. This means that the more customers do word of mouth, the more effect torepurchase intention. The company needs to be able to build positive word of mouth to customers in order to influence others to do repurchase intention at Muslimah Care Beauty Salon Padang. If the store can do this thing very well and then the store will be able to keep survive.

The results are consistent with previous studies conducted by (Ary dkk, 2016) who finds that word of mouth has significant effect to repurchase intention at PT. Tronik Lintas Nusantara Semarang. 
Furthermore, according (Leonnard dkk, 2017) a study finds that word of mouth is significantly affecting the repurchase intention.

\section{The Effect of Brand Image to Repurchase Intention}

Based on analysis result, it can be seen P-value of 0.000 which indicates that brand image has significantly positive effect to repurchase intention in Muslimah Care Beauty Salon Padang. This means that the better brand image will affect more repurchase intention. As a result, Muslimah Care Beauty Salon Padang is able to build positive brand image to customer's repurchase intention.

This result is in line with previous study conducted by (Komang \& I wayan, 2017) who finds that brand image significantly affects repurchasing intention to smartphone product entitle ASUS. In addition, according to (Maya et al, 2015) in his research finds that positive effect of brand image has positive effect as well on Samsung Galaxy Series.

\section{The Effect of Service Quality to Brand Image}

Based on analysis result, it can be seen P-value of 0.000 which indicates services quality has significantly positive effect to brand image Muslimah Care Beauty Salon Padang. This means that the better services quality, the greater impact to brand image. This means that in order to build a positive brand image in customer's mind, Muslimah Care Beauty Salon Padang needs to improve services quality, attention to the performance of employees, and keep product quality.

The result is in line with previous studies conducted by (Nisrul, 2008) who findst that services quality has positive and significant impact on brand image on internal medicine clinic dr. Pirngadi in Medan. Furthermore, according to Mohammad Rizan et al (2015) in his research finds that services quality has significantly positive effect to brand image on Gojek service application at the State University of Jakarta.

\section{The Effect of Location to Brand Image}

Based on analysis result, it can be seen P-value of 0.446 which indicates that location does not give positive and significant impact to brand image Muslimah Care Beauty Salon Padang. This means that location can not build a brand image on customer's minds.

The results of this study contrast with previous studies conducted by (Dewi Dkk, 2015) who finds that Service Marketing Mix (7P) has significant influence on brand image variable (Survey Participant Course and Training Institute Royal English Toefl \& Toeic Center Malang). Furthermore, Alma (2009) says that positive image of company can be formed by developing marketing strategies, implementing 7P (including location) where a gret meal will give positive impression to consumers, as a result consumers will trust and be able to establish positive brand image in their mind.

\section{The Effect of Word Of Mouth to Brand Image}

Based on the analysis, it can be seen P-value of 0.001 indicating word of mouth has positive and significant impact on brand image Muslimah Care Beauty Salon Padang. This means that increasing word of mouth, the more influence on brand image. In order to build a positive brand image in consumer's mind, Muslimah Care Beauty Salon Padang needs to build positive word of mouth on customer and this will affect people to come and buy.

The results are consistent with previous studies conducted by (Aditya, 2016) finds that word of mouth has significant to brand image on Telkom University students. Furthermore, according to (Ayu, 2008) in his research finds that word of mouth has positive and significant impact on brand image (Studies in Samyang Hot Spicy Chicken Noodle Products in Denpasar).

\section{The Effect of Services Quality to Repurchase Intention through Brand Image}

Based on the analysis above, it can be seen that P-value 0.000 indicates that services quality has significantly positive effect on repurchase intention through brand image Muslimah Care Beauty Salon Padang. This shows that services through brand image indirectly has positive and significant impact on repeat purchase interest. This means that the better the quality of service will affect the brand image. This means that services quality will affect the more customers to make purchase as long it is mediated by brand image. So Muslimah Care Beauty Salon Padang needs to be able to build positive brand image in order to keep survive in business competitive proliferation. 
The results are in line with previous research conducted by I Made (2019) finds that store image is significantly positive effect to services quality on repurchase intention which means that store image is able to affect services quality on Carrefour purchase. It can be concluded that there is positive relationship between quality of service and repurchase intention Muslimah Care Beauty Salon Padang.

\section{The Effect of Location to Repurchase Intention through Brand Image}

Based on analysis result, it can be seen P-value of 0.446 indicates location does not give positively significant effect to repurchasing intention through brand image at Muslimah Care Beauty Salon Padang. This means that a good location does not give a significant effect on brand image.

The results of this study are not consistent with previous studies conducted by Dewi Lelyana et al (2015) who finds that location variable has a significant influence on brand image variable (Survey Participant Course and Training Institute Royal English Toefl \& Toeic Center Malang). Further research conducted by Bahram (2012) finds that brand image has significant influence on repurchase intension in Irianian Department Stores.

Further research by author contradicts with the previous research because of the data reveals that location does not give positively effect to repurchase intention.

\section{The Effect of Word of Mouth to Repurchase Intention through Brand Image}

Based on the analysis, it can be seen P-value of 0.006 indicating that Word of mouth has positively significant effect to repurchasing intention through brand image at Muslimah Care Salon in Padang. This shows that brand image has positive and significant effect to mediation of word of mouth to make repurchase intention. This means that the better word of mouth, the more impact on brand image, has indirectly significant effect on repurchase intent.

The results are consistent with previous studies conducted by(M.Dian et al, 2016) finds that Word of mouth has positive and significant effect to repurchase intention in Institute for English Language Courses Dynamic English Course, Pare. It can be concluded that there is positive relationship between word of mouth and repurchase intention through brand image at Muslimah Beauty Salon Care Padang.

\section{Conclusion}

Based on analysis result and discussion, it can be concluded that services quality, and word of mouth has significant impact and positively influence to rephurchase intention variable through brand image at Muslimah Salon Beauty Care Padang. On the other side, location variable has no significant impact to repurchase intention through brand image. Based on the research result, there are some points to consider in order to increase purchasing decision as follow: (1). On brand image variable, the researcher suggest Salon to build brand image in order to attract customers; (2). On quality of care variable, the researchers suggest Salon to provide the better services that will make consumers has better impression and can make repurchase intention; (3) On location variable, the researchers suggest Salon to find accesible place so it will be easy for costumers to find and easy to open store branchess; (4) On word of mouth variable, researchers suggest Salon to provide words of mouth in order to give positive impression to customers as a result they will make a repurchase intention.

\section{References}

Aditya. 2016. "The effect of word of mouth on brand image dota 2 In telkom university students" eProceeding of Management : Vol.3, No.1 April 2016

Adixio, Riko Firmawan and Saleh, Laila (2013)." The influence of service quality and perceived value on the intention to repurchase through the medias of Solaria restaurant customer satisfaction in Surabaya. "Journal of Business and Banking .Volume 3, No. 2, November 2013, pages 151 -164

Afriani dan herman. 2015. "The Effect of Product Quality and Service Quality on Customer Satisfaction and Repurchase Interest (McDonald Alauddin Makassar). JOURNAL OF ORGANIZATION AND MANAGEMENT Volume 3 (September, 2015) 
Agyapong, G.K.Q. (2011). The Effect of Service Quality on Customer Satisfaction in the Utility Industry - A Case of Vodafone (Ghana). International Journal of Business and Management, 6 (5), h: $1-15$.

Ary dkk. 2016. "The effect of service, reputation, preference and Word of mouth on repurchase intention (case study on PT. Ntronik Lintas Nusantara, Semarang) " . Journal Of Management, Volume 2 No.2 Maret 2016

Awi, Y. L., \& Chaipoopirutana, S. (2014, August). A Study of Factors Affecting Consumer's Repurchase Intention toward XYZ Restaurant in Myanmar. International Conference on Trends in Economics, Humanities, and Management.

Ayu. 2018. "The role of Brand Image mediates the Effect of Word of Mout on Purchase Intention (Study of Samyang Hot Spicy Chickendi Noodle Products in Denpasar City) ".E-Jurnal Manajemen Unud, Vol. 7, No. 4, 2018 ISSN : 2302-8912 DOI: https://doi.org/10.24843/EJMUNUD.2018.v7.i04.p03

Basalamah, Fauzan M., 2010. Effect of Brand Communities on Word of Mouth. Jurnal Ilmun Administrasi dan Organisasi, 17 (1), hal.79-89.

Basu Swastha, dan Irawan, 2003, Modern Marketing Management, Yogyakarta, Publisher : Liberty Yogyakarta.

Bhuwana, Made Bagus Rangga dan Ida, Bagus Sudiksa.(2013). The Effect of Service Quality and Customer Satisfaction on the Intention of Reusing Service Services at the Toyota Auto 2000 Workshop in Bali Province. E-Jurnal Manajemen Universitas Udayana, 2 (4), h: 2302-8912.

Buchari, Alma,2009., Marketing and Marketing Services Management, Eighth Mold, Bandung : Alfabeta

Dewi dkk. 2015. "Effect of service marketing mix on the brand image and its impact on purchasing decisions". Jurnal Administrasi Bisnis . Vol. 24 No. 1Juli2015

Fandy Tjiptono. 2006. Service Management. First edition.Yogyakarta :Andi

Iput. 2007," Word of Mouth Management Defeats the Effects of Emen Advertising Services. First edition ", http://nero.com/link.php, diakses tanggal 6 mei 2011

Joseph, O., Onyemachi, Lilian, K.-O., \& Okpara, M. (2012). Analysis of the Determinants of Repurchase Intention of Soap Products of an Agribusiness Firm on Abia State, Nigeria. Journal of Economics and Sustainable Development, 3.

Kotler, Philip dan Kevin Lane Keller. 2009. Marketing Management (Jilid 1).Terj. Bob Sabran. Jakarta: Erlangga.

Kusuma, Made Andi. (2016). The Effects of Celebrity Endorse, Brand Image, and Product Quality on the Intention of Buying Bicycles Moto Honda Vario 125 in the City of Bali Province. Journal of the Faculty of Economics and Business, Udayana University, Bali Province.

Leonnard dkk. 2017. "The relationship of service quality, word-of-mouth, and repurchase intention in online transportation services". Journal of Process Management - New TechnologiesInternational Vol. 5, No 4, 2017.

Lupiyoadi, Rambat. 2013.Service Marketing Management. Edisi Ketiga. Jakarta: Salemba. dan A. Hamdani. 2008. Service Marketing Management . Jakarta: Salemba Empat.

M.Dian et al. 2016. "Word of Mouth Influence on Purchase Intention Through Imagen Brands at Dynamic English Course Pare English Course Institutions ". Jurnal Ekonomi Universitas Kadiri Vol. 1, No. 2, September 2016 DOI: 10.30737/Ekonika.V1i2.14

Maya et al. 2015. "Effects of Perceived Value and Brand Image on Repurchase Intention through Word of Mouth as Intervening Variables of Samsung Galaxy Series Smartphones " Diponegoro Journal of Social and Political of Science Tahun Vol.1 No.1 2015, Hal 1-9

Nadya. 2015. "Effect of Service Quality on Interest in Repurchasing Samsung Galaxy Series Smartphones". E Proceeding of Management : Vol.2, No.3 Desember 2015. ISSN : 2355-9357

Ni Komang dan I wayan. 2017. "The influence of brand image, brand association, and brand awareness on the repurchase intention of Asus brand smartphone products ". E-Jurnal Manajemen Unud, Vol. 6, No. 8, 2017: 4099-4126 ISSN : 2302-8912 
Nisrul dan Rina. 2008. "The influence of service quality on brand image in the outpatient unit of the internal medicine clinic, Dr. pirngadi in the field". Jurnal Manajemen Bisnis,Volume 1, Nomor 2, Mei 2008

Permadi, Prima C., Srikandi K., dan Andriani K. 2014. "The Influence of Brand Image on Word of Mouth and Purchasing Decisions (Survey on Mie Dapoer Consumers Is Disturbed at Selorejo 83 Malang)". Jurnal Administrasi Bisnis (JAB), 10 (1), hal.2-7.

Pupuani, N. W., \& Sulistyawati, E. (2013). "Effect of Marketing Mix on Consumer Satisfaction and Repurchase Behavior (Case Study on Pepsodent Brand Toothpaste Products in Denpasar City)". E-Jurnal Management, 2.He, Meixian, Zhenquan, Yang Yuanyuan band. 2013. "an Empirical Study On Impact Of

Rahmi. 2016. "Effect of location, product completeness, product quality, service, price, and convenience Shopping against consumer repurchase interests At lotte mart bekasi junction". Jurnal Administrasi Bisnis (JAB) |Vol. 24 No. 1Juli2015

Shimp, Terence A. (Harya Bhima Sena, Fitri Santi, Annisa Puspita Dewi, Penerjemah). 2014. Intergrated Marketing Communication in Advertising and Promotion. Jakarta: Salemba Empat.

Tariq, M.I., M.R. Nawaz., M.M Nawaz., and Hasim Awaiz Butt. (2013). Customer Perception About Branding and Puchase Intention : A Study of Fincgin an Emerging Market. Journal Of Basic and Applied Scientific Research, 3 (2), h: 340-347.

Tjiptono, Fandy dan Gregorius Chandra. 2011. Service,Quality and Satisfaction (ed 3). Yogyakarta. Andika

Triastuti, Freida. (2012). Analysis of the Effect of Service Quality, Product Quality, and Sales Promotions Against Repurchase Interests (Study on Consumers Koffee and Jazz Bouquet). Jurnal Fakultas Ekonomika dan Bisnis

Ujang Sumarwan. 2004. Consumer Behavior Theory And Its Application In Marketing, Bogor, Ghalia Indonesia.

Wibowo, Sarwo Eddy., Endang Ruswanti., dan Unggul Januarko. (2013). Effect of Service Quality Perception on Intent of Repurchase at Gramedia Bookstore Yogyakarta. Jurnal Ekonomi, 4 (1).

Yudi dkk. 2016. "The Effect of Service Quality, Location and Word Of Mouth on Repurchase Interests in the Padang Motorbike Repair Shop". Jurnal Manajemen dan Kewirausahaan, Volume 7, Nomor 3, September 2016 ISSN: 2086-5031

Yudi dkk. 2016. "The Effect of Service Quality, Location and Word Of Mouth on Repurchase Interests in the Padang Motorbike Repair Shop". Jurnal Manajemen dan Kewirausahaan, Volume 7, Nomor 3, September 2016 ISSN: 2086-5031

Yulianti, Ni Made Dhian Rani et al. (2014). Effect of Store Image on Customer Satisfaction and Intention to Repurchase at Circle K in the City of Bali Province, Jurnal Manajemen Strategi Bisnis dan Kewirausahaan, Vol.8, No.1, pp. 36-44. 